\section{(C) OPEN ACCESS}

\title{
Neck-tongue syndrome
}

\author{
Eric Chun Pu Chu, Andy Fu Chieh Lin
}

Chiropractic and Physiotherapy Department, New York Medical Group, Mong Kok, Hong Kong, Hong Kong

\section{Correspondence to Dr Eric Chun Pu Chu, eric@nymg.com.hk}

Accepted 12 November 2018

Check for updates

(c) BMJ Publishing Group Limited 2018. Re-use permitted under CC BY-NC. No commercial re-use. See rights and permissions. Published by BMJ.

To cite: Chu ECP, Lin AFC. BMJ Case Rep

2018:11:e227483.

doi:10.1136/bcr-2018-

227483

\section{SUMMARY}

Neck-tongue syndrome (NTS) is a rarely reported disorder characterised by paroxysmal episodes of intense pain in the upper cervical or occipital areas associated with ipsilateral hemiglossal dysaesthesia brought about by sudden neck movement. The most likely cause of this clinical entity is a temporary subluxation of the lateral atlantoaxial joint with impaction of the C2 ventral ramus against the articular processes on head rotation. NTS is an under-recognised condition that can be debilitating for patients and challenging for the treating physicians. Here, we report a 47-year-old man who fulfilled the International Classification of Headache Disorders, third edition criteria for a diagnosis of NTS was treated successfully with a chiropractic approach. There are currently no consensus guidelines for dealing with this disorder. Reassuringly, chiropractic care for uncomplicated NTS appears highly effective.

\section{BACKGROUND}

Neck-tongue syndrome (NTS) is a rarely reported disorder. Plausible speculations on its pathophysiology have recently been described in case reviews. ${ }^{1-3}$ It is characterised by brief attacks of occipital pain and ipsilateral hemiglossal dysaesthesia elicited by abrupt neck rotation. ${ }^{4}$ Although NTS can occur without obvious abnormalities, associated pathological changes include degenerative spondylosis, ankylosing spondylitis, psoriatic arthritis and loose ligaments of joint capsules. ${ }^{5}$

According to the ICHD-3 (International Classification of Headache Disorders, third edition) criteria, ${ }^{6}$ to be diagnosed as having NTS, a person must display: (A) at least two episodes fulfilling criteria B-D; (B) sharp or stabbing unilateral pain in the upper neck and/or occipital region with concurrent abnormal sensation and/or posture of the ipsilateral tongue (may or may not be simultaneous dysaesthesia); (C) episodes triggered by sudden neck turning; (D) symptoms lasting from seconds to several minutes; (E) clinical features not better accounted for by another ICHD-3 diagnosis. Imaging is primarily used to search for secondary causes amenable to more aggressive medical treatment or surgical intervention. ${ }^{7}$ This presentation aims to shed some light on the understanding of this intriguing entity.

\section{CASE PRESENTATION}

A 47-year-old man sought chiropractic treatment for paroxysmal episodes of right hemicranial pain and tingling of the right face and ipsilateral hemitongue for 3 months. His trouble had begun with a dry cough and dysarthria which resolved spontaneously within 2 weeks. The patient described his headache as right suboccipital pain spreading across the anterior hemicranium to the periorbital and maxillary regions, with tingling of the right half of the tongue. The pains were brought out by an abrupt head turning to the right, forward neck glide or chewing. Symptoms usually lasted for minutes. He had no prior head and neck trauma, or systemic disorders. At first, the patient was examined by a neurologist. There was no elevation in white blood cell count, erythrocyte sedimentation rate and C reactive protein. Routine chemical parameters fell within normal ranges. Rheumatoid factor and antinuclear antibody were negative. His clinical features fulfilled the ICHD-3 criteria for a diagnosis of NTS. ${ }^{6} \mathrm{He}$ had been on oral gabapentin and diclofenac which did not provide substantial pain relief. After a month or so, he stopped taking the analgesics because of unacceptable stomach upset. He ultimately came to chiropractic attention for the above complaints.

\section{INVESTIGATIONS}

At the initial visit, the patient presented with guarded neck posture. He described a headache as sharp and 6/10 in intensity on the numeric pain scale (NPS). Active range of cervical extension was restricted to $10^{\circ}$ (normal $>60^{\circ}$ ) and rotation to $30^{\circ}$ (normal $>80^{\circ}$ ). Palpation revealed hypertonicity of the suboccipital and sternocleidomastoid muscles. Physical, neurological and ophthalmic investigations were consistently unremarkable. Cervical radiographs demonstrated narrowing of the right paraodontoid space on open mouth view and degenerative changes in the lower cervical spine, suggestive of degenerative spondylosis.

\section{TREATMENT}

The first phase of chiropractic regimen was in an attempt to mobilise the restricted joints and to release what was reasoned to be an impacted nerve. The cervical musculature was appropriately stretched before spinal adjustment to ensure that NTS was not provoked. The patient was treated with three sessions per week.

Following 12 sessions, pain frequency and intensity had significantly decreased. A unilateral headache was then rated to be $3 / 10$ on the NPS. The distribution of facial pain was reduced and localised to the right parotid region. The second phase of treatment was to relax hypertonic muscles and strengthen weak muscles. Treatment programme included ultrasound therapy over the right face, trigger point therapy of the right temporalis, 
masseter and sternocleidomastoid muscles, and corrective exercise for neck posture was set for the patient three times a week for the next 4 weeks.

\section{OUTCOME AND FOLLOW-UP}

Following 24 visits, the painful episodes had disappeared and the active range of neck motion had increased. There was minimum residual dysaesthesia in both the right face and hemitongue. Since the patient had significantly been improved, he was given a home exercise programme and monitored. At the 3-month follow-up, he reported no further trouble. A headache and hemiglossal dysaesthesia were gone and could not be provoked.

\section{DISCUSSION}

The classic description of the NTS includes immediate-onset, unilateral, sharp occipital and/or upper neck pain elicited by sudden head rotation, accompanied by abnormal sensation and/ or posture of the ipsilateral hemitongue. ${ }^{6}$ NTS is a condition rarely described in a clinical practice. In a review published in 2018, there were only 39 primary cases reported in the English literature. ${ }^{3}$ However, NTS may actually be more frequent than hitherto surmised. ${ }^{8-11}$

The symptoms of NTS are quite reminiscent of a cervicogenic headache. ${ }^{1012}$ Most cases of NTS were likely submerged in the plethora of neck-related symptoms. ${ }^{13}$ The primary difference is that a cervicogenic headache is a referred pain from the musculoskeletal structures of the upper neck, ${ }^{14}$ and that the pain of NTS is rooted in the C2 spinal nerve. ${ }^{15}$ Head pain referred from cervical structures can be explained by the evidence that the first three cervical spinal $(\mathrm{C} 1-\mathrm{C} 3)$ nerves relay pain signals to the trigeminocervical nucleus, which allows the bidirectional referral of painful sensations between the neck and trigeminal sensory receptive fields of the face and head. ${ }^{9}{ }^{14}$ By the International Headache Society, NTS is to be listed as a painful lesion of the cranial and spinal nerves. ${ }^{6}$ The pain of NTS is in the distribution of the C2 nerve root. ${ }^{15}$ Neuralgia of C2 is classically described as a deep or dull pain that usually radiates from the occipital to parietal, temporal, frontal and periorbital regions. ${ }^{714}$

It is acknowledged that the $\mathrm{C} 2$ dorsal ramus gives rise to the greater occipital nerve innervating the majority of the posterior scalp, ears and parotid region. ${ }^{16}$ The $\mathrm{C} 2$ and its dorsal root ganglion have a close proximity to and innervate the atlantoaxial (C1-2) and C2-3 zygapophyseal (facet) joints. ${ }^{74}$ Thus, on head rotation, inflammation or pathological changes of these joints may lead to irritation or entrapment of the nerve root. ${ }^{1417}$ The afferent fibres from the lingual nerve anastomose with the hypoglossal nerve and return to the $\mathrm{C} 2$ ventral ramus via the cervical plexus. ${ }^{9}{ }^{15}$ The afferents, thought to be proprioceptive, ${ }^{1}$ provide a plausible explanation for the compression of the $\mathrm{C} 2$ ventral ramus causing episodic paraesthesia of the hemitongue. ${ }^{9}{ }^{18}$ The phenomenon of lingual pseudoathetosis seen in NTS is speculated as a result of the presumed lingual deafferentation. ${ }^{1}$ Since the $\mathrm{C} 2$ ventral ramus exits beneath the obliquus capitis inferior muscle, Cassidy et al further proposed that the inflamed or spastic muscle could also result in the compression or entrapment of the $\mathrm{C} 2$ ramus, ${ }^{4}$ providing a possible explanation for spontaneous resolution of the painful syndromes. Given the rarity of NTS, however, no one unifying explanation has emerged from the literature that explains all symptoms and presentations associated with this entity. ${ }^{12}$

NTS is a clinical diagnosis that can be made with a fulfilment of the ICHD-3 criteria and via a process of exclusion. ${ }^{615}$ Diseases of the eyes, ears, nose, throat and teeth may coexist and confuse the diagnosis. Radiographic evaluation of the cervical spine is usually normal. However, MRI can identify brain lesions, sinus disease, infection and other abnormalities responsible for the patient's neurological symptoms. ${ }^{15}$ A complete blood cell count, erythrocyte sedimentation rate and automated chemistry profile are indicated to rule out infection, temporal arteritis and malignancy that may mimic NTS. ${ }^{15}$

The limited number of cases of NTS in the literature makes it impossible to generalise regarding the natural history and optimal treatment for this entity. Of the 23 published cases of NTS rendering treatment discussion, Borody observed in his review that more than a half of the cases $(n=13 / 23)$ were treated directly with a chiropractic adjustment. All the 13 patients reported a significant reduction in pain intensity and in episode frequency. ${ }^{8}$ In other case reports, patients had had their symptoms relieved by medications, ${ }^{19}$ physiotherapy, ${ }^{20}$ immobilisation with cervical collars, ${ }^{13}$ local injections ${ }^{1}$ and rarely surgical intervention. $^{2} 21$

Our patient above benefitted from cervical adjustment and this appears to support that cervical adjustment could be an effective approach for some cases of NTS. However, the atlantoaxial (C1-2) joint is most vulnerable to injury since there are no intervertebral disc fibres and no interlocking joints to limit rotation. Therefore, a careful consideration of applying a minor manipulation in the upper cervical area is stressed. The main limitation of our report is that the exact mechanism of chiropractic adjustment in the amelioration of NTS has not yet been established. Further studies elucidating the exact mechanism via chiropractic adjustment are needed before any categorical statements regarding its efficacy for NTS can be made.

\section{Learning points}

- Neck-tongue syndrome (NTS) is characterised by unilatera headache triggered by head turning and accompanied by dysaesthesia of the ipsilateral hemitongue.

- The pain of NTS is in the distribution of the C2 nerve root.

- NTS is rarely reported but may be more frequent than hitherto surmised.

- Conservative management, including physiotherapy and minor cervical adjustment, may be the preferred initial treatment.

Contributors ECPC: conceived and wrote the manuscript as main author. AFCL: critically reviewed and helped organise the manuscript. All authors: read and approved the final manuscript.

Funding The authors have not declared a specific grant for this research from any funding agency in the public, commercial or not-for-profit sectors.

Competing interests None declared.

Patient consent Obtained.

Provenance and peer review Not commissioned; externally peer reviewed.

Open access This is an open access article distributed in accordance with the Creative Commons Attribution Non Commercial (CC BY-NC 4.0) license, which permits others to distribute, remix, adapt, build upon this work non-commercially, and license their derivative works on different terms, provided the original work is properly cited and the use is non-commercial. See: http://creativecommons.org/ licenses/by-nc/4.0/

\section{REFERENCES}

1 Orrell RW, Marsden CD. The neck-tongue syndrome. J Neurol Neurosurg Psychiatry 1994;57:348-52

2 Hu N, Dougherty C. Neck-Tongue Syndrome. Curr Pain Headache Rep 2016;20:27 https://doi.org/. 
3 Gelfand AA, Johnson H, Lenaerts ME, et al. Neck-Tongue syndrome: A systematic review. Cephalalgia 2018;38:374-82.

4 Cassidy JD, Diakow PRP, De Korompay VL, et al. Treatment of neck-tongue syndrome by spinal manipulation: a report of three cases. Pain Clin 1986;1:41-6.

5 Maheshwari PK, Pandey A. Unusual headaches. Ann Neurosci 2012:19:172-6.

6 Headache Classification Committee of the International Headache Society (IHS). The International Classification of Headache Disorders: 3rd edition. Cephalalgia 2018;38:1-211.

7 Kraemer J, Pal J, Bajwa ZH. Headaches other than migraine: In. Smith H, ed. Current Therapy in Pain. 1st edn. Philadelphia, PA: Saunders, 2009:111-20.

8 Borody C. Neck-tongue syndrome. J Manipulative Physiol Ther 2004;27:367.

9 Bogduk N. An anatomical basis for the neck-tongue syndrome. J Neurol Neurosurg Psychiatry 1981;44:202-8.

10 Sjaastad 0, Bakketeig LS. Neck-tongue syndrome and related (?) conditions. Cephalalgia 2006;26:233-40.

11 Queiroz LP. Unusual headache syndromes. Headache 2013;53:12-22.

12 Sidlow JS, Raden MJ, Sidlow R. Neck-tongue syndrome: Viewpoints on etiology in a patient with bilateral symptoms. Case Rep Neurol Med 20182018;2018:1-3.
13 Webb J, March L, Tyndall A. The neck-tongue syndrome: occurrence with cervical arthritis as well as normals. J Rheumatol 1984;11:530-3.

14 Biondi DM. Cervicogenic headache: a review of diagnostic and treatment strategies. J Am Osteopath Assoc 2005;105-165-22.

15 Waldman SD. Neck-tongue syndrome: In. Waldman SD, ed. Atlas of Uncommon Pain Syndrome. 3rd ed. Philadelphia, PA: Saunders, 2014:72-3.

16 Koca T. Occipital nerve blockage in cervicogenic headache: A case report and brief review of literature. Medicine Science | International Medical Journal 2015:4:1972-8.

17 Poletti CE, Sweet WH. Entrapment of the C2 root and ganglion by the atlantoepistrophic ligament: clinical syndrome and surgical anatomy. Neurosurgery 1990:27:288-91.

18 Roberts CS. Chiropractic management of a patient with neck-tongue syndrome: A case report. J Chiropr Med 2016;15:321-4.

19 Chedrawi AK, Fishman MA, Miller G. Neck-tongue syndrome. Pediatr Neurol 2000;22:397-9.

20 Niethamer L, Myers R. Manual therapy and exercise for a patient with neck-tongue syndrome: A case report. J Orthop Sports Phys Ther 2016:46:217-24.

21 Elisevich K, Stratford J, Bray G, et al. Neck tongue syndrome: operative management. J Neurol Neurosurg Psychiatry 1984;47:407-9.

Copyright 2018 BMJ Publishing Group. All rights reserved. For permission to reuse any of this content visit https://www.bmj.com/company/products-services/rights-and-licensing/permissions/ BMJ Case Report Fellows may re-use this article for personal use and teaching without any further permission.

Become a Fellow of BMJ Case Reports today and you can:

- Submit as many cases as you like

- Enjoy fast sympathetic peer review and rapid publication of accepted articles

- Access all the published articles

- Re-use any of the published material for personal use and teaching without further permission

For information on Institutional Fellowships contact consortiasales@bmjgroup.com

Visit casereports.bmj.com for more articles like this and to become a Fellow 